\title{
Geological Lineament Detection, Characterization and Association with Groundwater Contamination in Carbonate Rocks of Musandam Peninsu- lar Using Digital Elevation Model (DEM)
}

\author{
Samy Ismail Elmahdy ${ }^{1, *}$ and Mohamed Mostafa Mohamed ${ }^{1,2}$ \\ ${ }^{I}$ Civil and Environmental Engineering Department, United Arab Emirates University, P.O. Box 17555, Al-Ain, United \\ Arab Emirates \\ ${ }^{2}$ Irrigation and Hydraulics Department, Faculty of Engineering, Cairo University, P.O. Box 12211, Giza, Egypt
}

\begin{abstract}
Geological lineaments play vital role in groundwater recharge, groundwater discharge toward the sea. For this purpose, topographic fabric algorithm which uses a digital elevation model (DEM) to create maps of ridges and valleys was used to carry out all geological lineaments crosscutting the entire Musandam Peninsula, UAE and Oman. Six sets of geological lineaments deform the carbonate aquifer of Musandam Peninsula, UAE and Oman. Their orientations were found to be in the NW-SE,NNW-SSE,NE-SW,NNE-SSW, WNW-ESE and E-W directions. The most notable of these lineaments are tensional and dipping to the E-W, NNE-SSW and N-S. The extracted geological lineaments were spatially correlated with previously groundwater samples collected from Al Bih well field. The results of the study reveal that the Musandam carbonate aquifer is structurally controlled by geological lineaments that have been produced by successive tectonic events, significantly influencing groundwater salinity and groundwater temperature of Al Bih well field indicating the efficient of the proposed method.
\end{abstract}

Keywords: Musandam, Geological lineaments, Wadi Al Bih, Sea water intrusion.

\section{INTRODUCTION}

In arid and semi-arid regions, groundwater consuming has led to sharp deterioration in groundwater quality and quantity [1-4]. Additionally, groundwater over pumping has led to dramatic depletion in groundwater tables in coastal and inland aquifers [2]. This study investigates the influence of geological lineaments as a secondary permeability and underground channels on hydrological setting of Musandam Peninsula, carbonate rock dissolution, and therefore, groundwater salinity of Al Bih well field.

Geological lineaments (faults and joints) are linear features that can be seen in satellite images, aerial photographs and digital elevation models [5, 6]. Fault escarpments, fold axis and rock bedding plains are other features belonging to tectonic activity [2]. These linear features can be interpreted as rift, linear valleys, linear slope breaks or linear ridgelines [7]. These features represent pass ways for groundwater accumulation, groundwater discharge and seawater intrusion into coastal and inland aquifers [8]. groundwater quality of fractured aquifers in carbonate rocks are typically low, compared to inland groundwater aquifers. Wells that produce groundwater of significance salts usually occur in fractures and fault zones that cut carbonate aquifers [9]. Many studies have been applied to study and mange groundwater contamination in carbonate and coastal aquifers $[1,4,6,9]$, the role

\footnotetext{
*Address correspondence to this author at the Civil and Environmental Engineering Department, United Arab Emirates University, P.O. Box 17555, Al-Ain, United Arab Emirates; Tel: +971-506895096;

E-mail: samy903@yahoo.com
}

of lineaments in groundwater contaminations $[2,8,11]$, well production increases with increasing lineament density, especially when the lineaments are intersected [6,12-14]. A high positive correlation $(\mathrm{r}=0.851)$ between lineament length density and yield was found, indicating a strong relationship between fracturing and well production [11, 14].

Unlike the conventional techniques, which based on traditional geological mapping [5-6], groundwater management $[1,3]$, isotope data analysis $[10,12]$, the topographic fabric algorithm using DEM was applied to Musandam peninsula of UAE and Oman in order to model regional geological lineaments to investigate the groundwater contamination in large scale with time and coast effectively. The shaded relief maps and grid derivative maps such as aspect, slope and curvature showed usefulness to automatically extract the geologic linear features [14-17]. However, it is possible to systematically verify remotely sensed lineaments and understand their nature using confidence estimates derived from suitable field observations [14, 17-19].

The main goal of this study was to precise extract geological lineaments that have been resulted by tectonic activity and investigate the influence of geological lineaments on groundwater setting and groundwater salinity of carbonate aquifer over multiplescale.

\section{STUDY AREA}

Musandam Peninsula is suited in the United Arab Emirates (UAE) and Oman on the south-eastern edge of the Arabian Peninsula between, $25^{\circ}, 30^{\circ} \mathrm{N}, 26^{\circ}, 10 \mathrm{~N}$ latitudes, $55^{\circ}$, $90 \mathrm{E}$ and $65^{\circ}, 30 \mathrm{E}$ longitudes (Fig. 1a) and covers an area of 


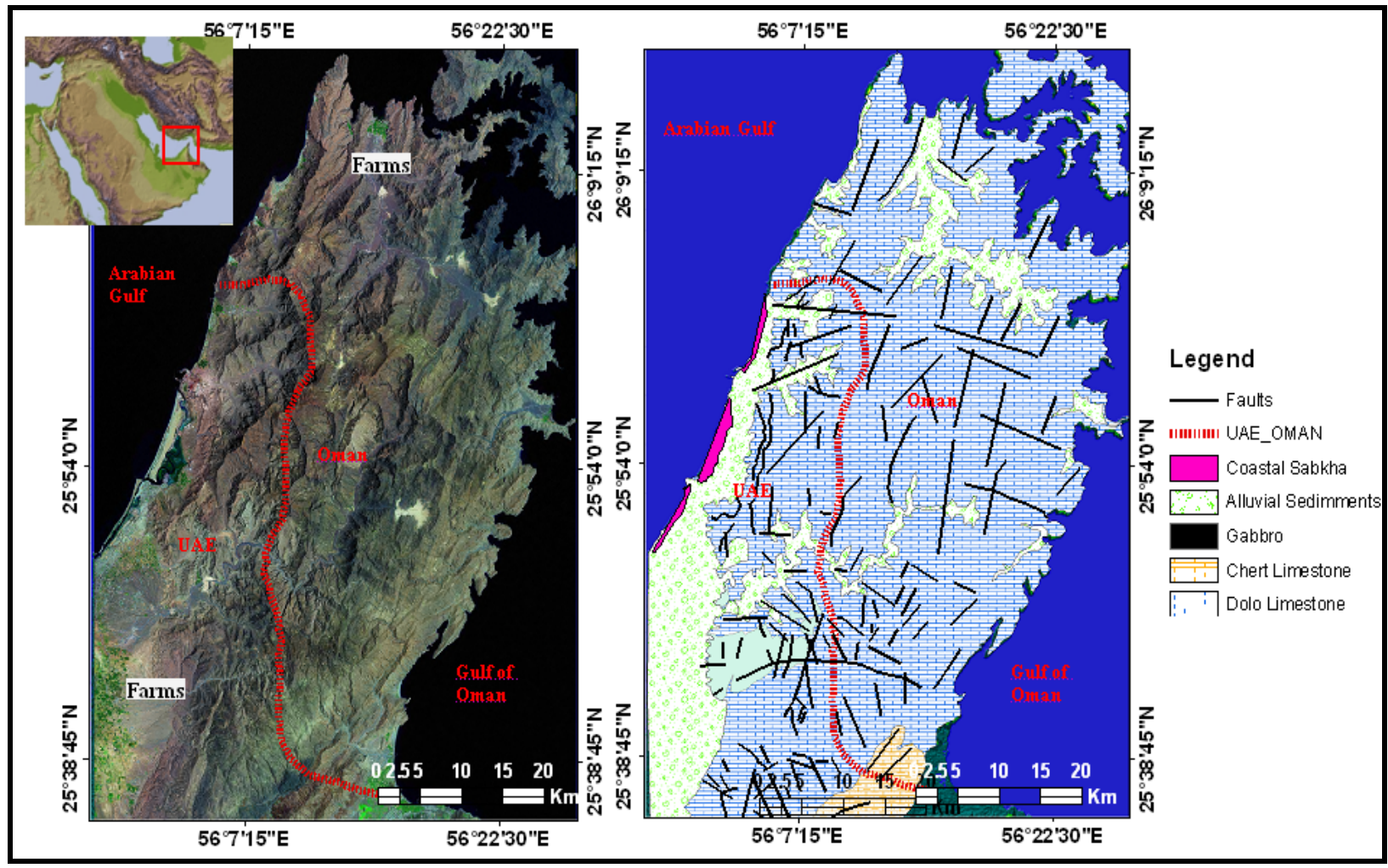

Fig. (1). LANDSAT TM image and (a) geological map (b) of the Musandam Peninsula, Oman and UAE.

about $70 \times 35 \mathrm{~km}$ or $1932.3 \mathrm{~km}^{2}$. It is essentially composed of intensive fractured carbonate rocks such as limestone and dolomite drained by several drainage networks (Fig. 1b). Altitude ranges from 5 in the lowlands to $2000 \mathrm{~m}$ in the central part of the study area. Slopes range from 0 to $60^{\circ}[20,21]$.

\subsection{Hydrological Setting}

The Musandam Peninsula is characterized by an arid climate $(160 \mathrm{~mm} / \mathrm{year})$ with hot during summer and warmer during winter with an annual rainfall less than $14.84 \mathrm{~mm}$ per event and $160 \mathrm{~mm}$ per year [22, 23]. Approximately $10 \%$ of this amount annually recharges the shallow and deep aquifers of groundwater [23].

The Musandam Peninsula is one of the highly fractured carbonate aquifer in which rain falls on highlands at an elevation of $2000 \mathrm{~m}$ and infiltrates directly into fractured carbonate rocks, main Wadis and into upper un-confined aquifer [10]. Groundwater aquifers can be divided into three groups: the coastal and narrow aquifer in the east and west, the inland aquifer in the southwest and the exposed mountainous aquifer in the middle. In the main Wadis (Al Bih and Khasab), groundwater aquifers can be divided into three major unites: the upper unconfined of friable and un-cemented alluvial deposits of $5 \mathrm{~m}$ in thickness, the middle semiconfined semi-cemented of calcium carbonate alluvial aquifer of $5 \mathrm{~m}$ in thickness and the lower confined fractured carbonate rocks [1]. In the Wadi Bih, which is part of the study area, approximately $9 \%$ or $6.7 \times 106 \mathrm{~m}^{3}$ of the total annual precipitation $\left(74 \times 106 \mathrm{~m}^{3}\right)$ becomes groundwater in the catchment [1]. According to [3], the vertical hydraulic conductivity of the alluvial gravel decreases from $10 \mathrm{~m} /$ day at the unconfined and un-cemented upper aquifer to $0.1 \mathrm{~m} / \mathrm{day}$ at the middle semi-confined and semi-cemented aquifer. The lateral hydraulic conductivity of the upper unconfined aquifer ranges from $32 \mathrm{~m} /$ day to $67 \mathrm{~m} /$ day [3], which can serve as channels for sideward transport of surface water. Underneath the upper and middle aquifers lies the deep highly fractured carbonate aquifer that form the main aquifer of the Musandam Peninsula. This aquifer consists of $100 \mathrm{~m}$ of dolomitic limestone follow to different geological times with an average lateral hydraulic conductivity of about $33 \mathrm{~m} /$ day [3]. About $40 \%$ of groundwater in Oman and the United Arab Emirates is produced from shallow alluvial aquifers $[1,10]$.

\subsection{Geological Setting}

The Musandam Peninsula forms a geological bond between late Tertiary continental and late Cretaceous Ophiolite Obduction tectonics of the Oman Mountains [21, 21, 24]. Tectonically, it belongs to the Hajar super-group, which is sub-divided into three groups: (1) Permian to middle Triassic Ru'us Jibal group (north), which includes Hagil, Bih and Gheil formations; (2) Middle to upper Triassic Elphinstone group including Milaha sandstone formation and Ghalilah dolomatic limestone formation and (3) Early Jurassic to Lower Cretaceous Musandam group [20, 21, 24]. It is asymmetrical anticline fold (Fig. 2) dominated by tremendous number of geological fractures that are the tectonic result of the late Cretaceous ophiolite obduction tectonics of the Oman Mountains and the late Tertiary continental collision tectonics of the Zagros Fold belt of Iran [20, 21, 24].

The study area is drained by dry NW-SE and NE-SW trending Wadis. These Wadis are covered with Quaternary alluvial deposits of $60 \mathrm{~m}$ in thickness, which affect the groundwater recharge and accumulation and represent unconfined and semi-confined aquifers $[1,2]$. 


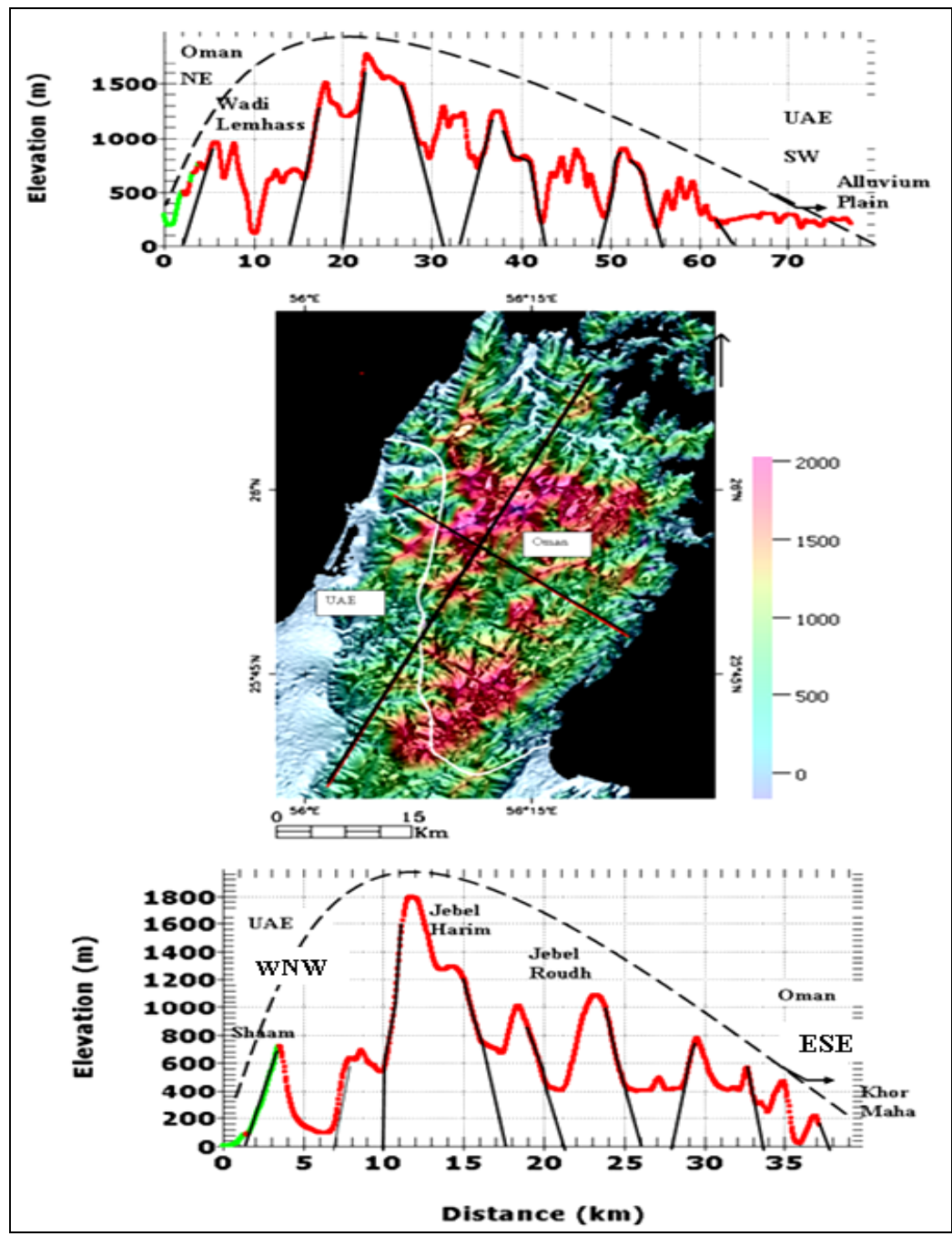

Fig. (2). NE-SW and WNW-ESE automatic profiles extracted from DEM showing the geological structure of the study area in terms of NESW asymmetrical fault fold.

\section{MATERIALS AND METHODS}

\subsection{Data and Pre-Processing Phase}

Two remotely sensed datasets were employed in this study. The first dataset was the Advanced Spaceborne Thermal Emission and Reflection Radiometer (ASTER) DEM has a spatial resolution $30 \mathrm{~m}$, geographic coordinate system is $\mathrm{UTM} / 84$, the theoretical absolute horizontal and vertical accuracy is up to $10 \mathrm{~m}$. The ASTER DEM is currently available from the Earth Remote Sensing Data Analysis Center (ERSDAC) database [25]. The ASTER DEM was found to be the suitable data due to the limitation of topograp

hic maps on regional scale.

Apart from the accompanying standard error report, there are some acceptable procedures used to estimate the overall quality of DEM [26]. First, the histogram of the elevation data itself and aspect were investigated. Second, the shaded relief of the DEM was visually investigated to see artifical structure. Third, depressions and spikes were derived from the DEM and investigated to identify if they are natural lakes or artificially introduced sinks. The second dataset was $30 \mathrm{~m}$ spatial resolution LANDSAT TM images are currently available from the NASA database [27].

\subsection{Automatic Extraction of Surface and Subsurface Geological Fractures}

Through contouring the normals to the earth's surface, statistical slope orientation diagram provides a tool for the calculation and display of orientation for an entire DEM [28]. He subsequently calculated and graphed the ratios for flatness, $\ln \left(\mathrm{S}_{1} / \mathrm{S}_{2}\right)$ and organization, $\ln \left(\mathrm{S}_{2} / \mathrm{S}_{3}\right)$. Then, combined, described and calculated flatness parameters, organization parameters (vector length) for terrain and eigenvectors (vector direction) for fabric shapes in structural geology and for the automatic characterization of terrain organization. The two most important morphometric classes proposed by were ridges (positive lineaments) which reflect the footwall of a fault zone and valleys (channels/negative lineaments) which reflect the fault zone itself.

The algorithm begins calculating slope and slope direction (aspect) which defines a vector normal to the earth's surface at each point. The algorithm then creates a $3 \times 3$ matrix of the sums of the cross products of the direction cosines of the landscape surface, obtaining the eigenvectors. The 

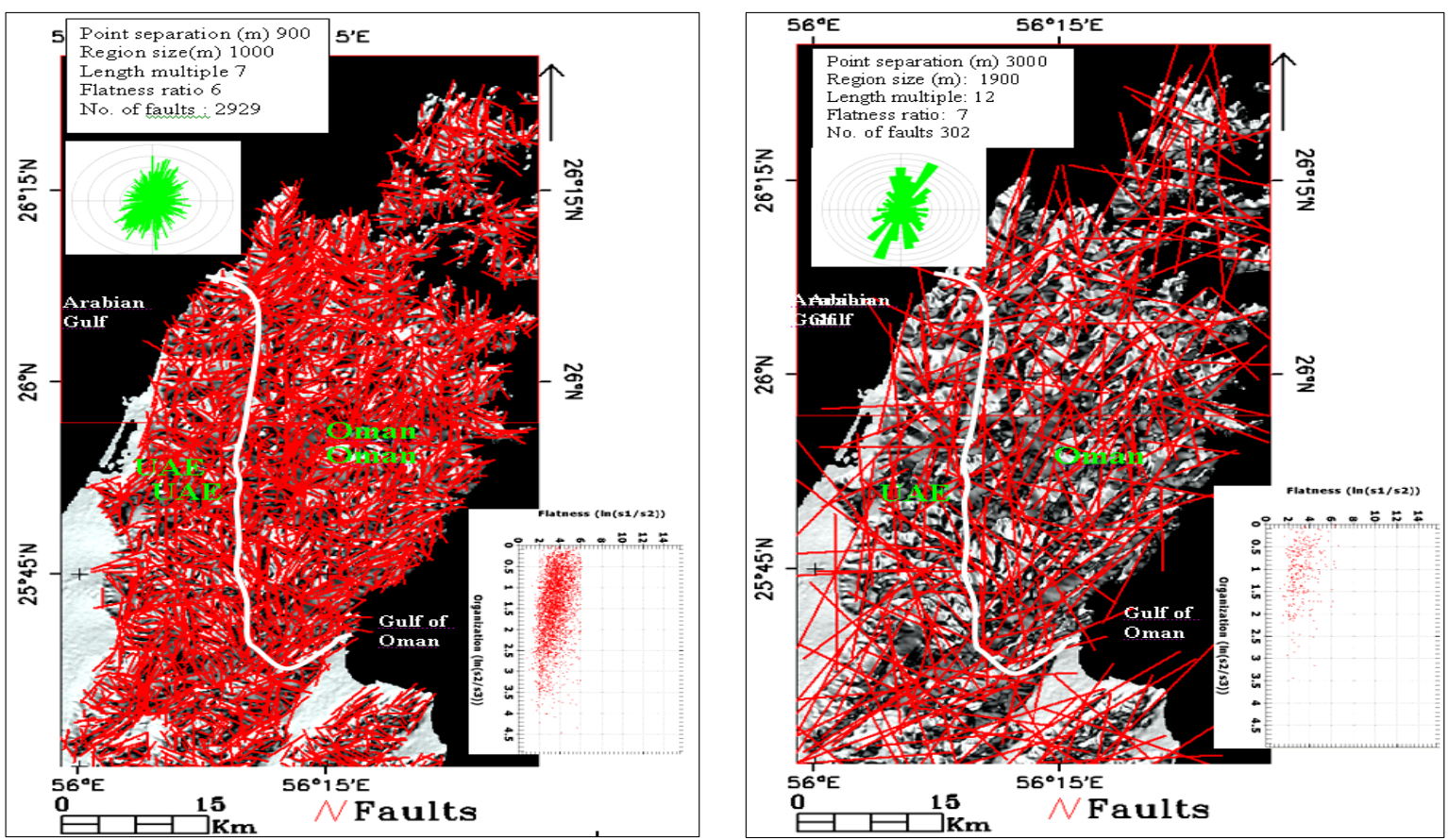

Fig. (3a). local geological lineaments and (b) regional faults extracted from DEM using topographic fabric algorithm. These are draped over shaded relief maps. Graphs of flatness versus organization show the influence of values of these parameters on the number and length of extracted geological lineaments. Rose diagrams highlight trends of geological lineaments.

ratio $\ln \left(\mathrm{S}_{1} / \mathrm{S}_{2}\right)$ acts as a flatness parameter, correlating perfectly with average slope. The ratio $\ln \left(\mathrm{S}_{2} / \mathrm{S}_{3}\right)$ reflects the strength of the preferred orientation.

The topographical fabric algorithm offers the option of extracting different lengths and directions of geological fractures, on the basis of changes in region size, point separation and flatness cut-off [28]. These three values are used to determine if a pixel quantifies as a ridge or a valley, with multiple length values used to determine geological fracture length.

As a first step, the algorithm requires proper parameter input from the interpreter. The first parameter, point separation in metres, is related to the distance between points at which the grain will be calculated. A higher point separation value decreases the number of geological fractures extracted. For example, distance between geological factures of $1200 \mathrm{~m}$, which is the higher point separation can be used to extract $10 \times 8$ vectors (revealed lineaments). The second parameter, region size, is related to the size of the blocks over which the fabric will be calculated. For example, a region size of $800 \mathrm{~m}$ corresponds $5 \times 5$ points/box. The third parameter, flatness cut-off, influences whether flatter points will or will not be plotted. The larger the value selected the more points will be plotted, but these may be subject to random noise [28].

The appropriate value depends on the pixel size of the DEM and the surface roughness of the region, determine the number of geological fractures extracted in areas of low slope and relief. The fourth parameter, multiple lengths, is related to the length of extracted geological fractures or the scaling factor for the length of fabric vectors. A higher value of multiple length results in longer geological fractures [28].

\section{RESULTS AND DISCUSSION}

The new maps of geological fractures crosscutting the entire carbonate aquifer of Musandam Peninsula extracted from DEM using different values of topographic fabric algorithm parameters are shown in Fig. (3). Geological fractures extracted from morphometric maps are the highest in frequency (Fig. 3a), but the lengths are shorter compared with those extracted using high values of length and point separation (Fig. 3b). The maps consist predominantly of three sets of geological fractures of different trending in the NNE-SSW, NW-SE and WNW-ESE that matched and controlled by Dibba, HAM and Hatta Fault zones. These geological fractures were visualized using the enhanced two 3D slope and aspect thematic maps ((Fig. 3).

According to the rose diagrams (Fig. 3), the common orientations of the fault displacements were found to be in the NW-SE, NE-SW and WNW-ESE directions that match the regional geological structure or the region (Fig. 1b). These features are the tectonic result of the late Cretaceous ophiolite obduction tectonics of the Oman Mountains and the late Tertiary continental collision tectonics of the Zagros Fold belt of Iran [20, 21].

The results reveal that the northern and southern parts of the Musandam Peninsula crosscutting by two sets of step low dipping regional normal faults. Their displacements were found to be in the WNW-SES and NW-SE directions, of approximately $35 \mathrm{~km}$ in length and deform Wadi Al Hablayn, Wadi Limhas and Wadi Khassb, Oman. On the other hand, two sets of regional faults characterize the east and west limbs of Musandam anticline. Their trending were found to be in the NE-SW and NNE-SSW directions and deform the northwestern narrow coastal plain in Tibat and Bukha, Oman and Ramass, Shaam, and Shams Al Qir, UAE (Fig. 2, 3).

Verification of the spatial association of the extracted geological fractures and groundwater well yield was made by 

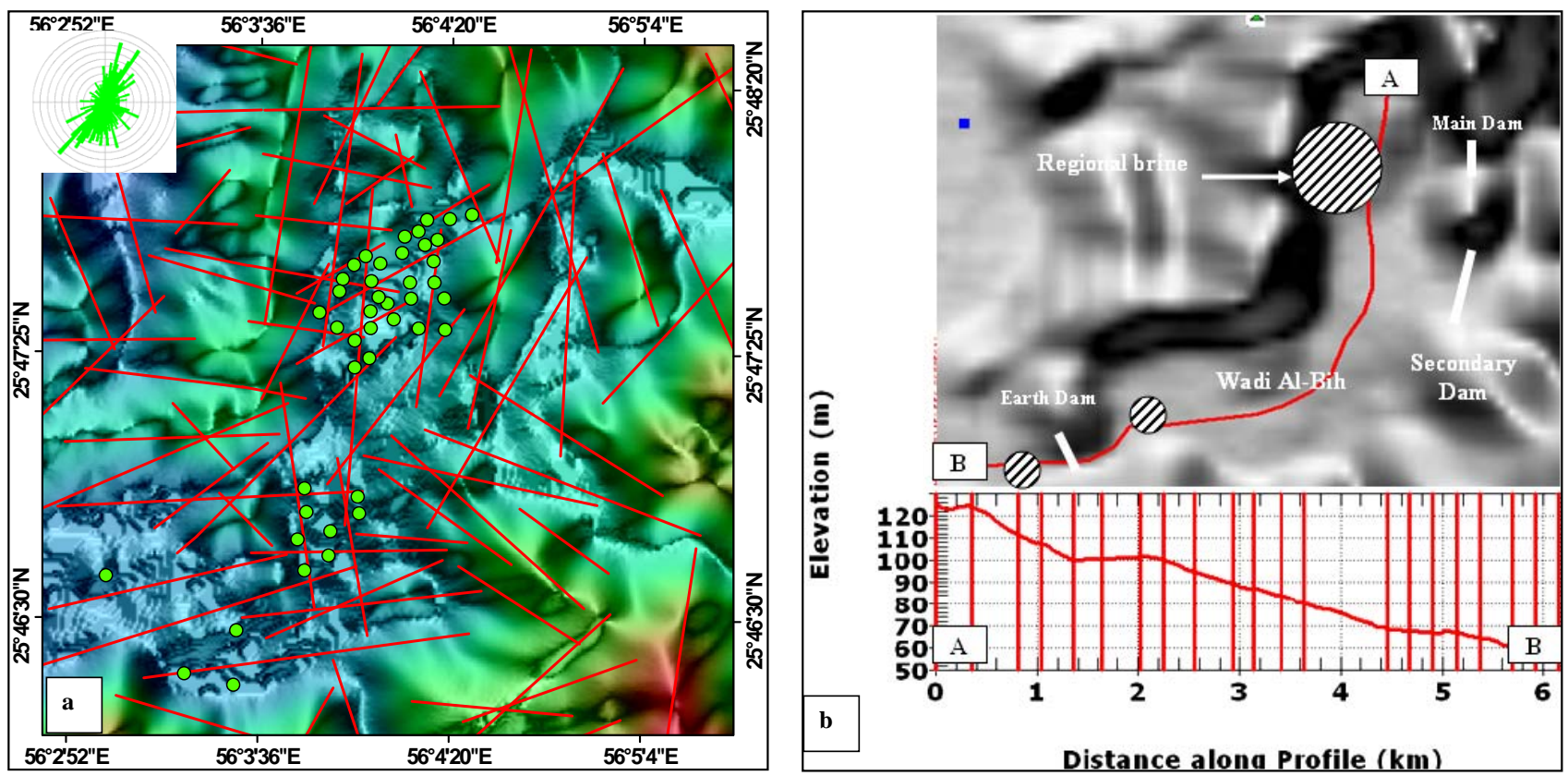

Fig. (4a). Al Bih well field and regional faults extracted from DEM using topographic fabric algorithm, and (b) their associated brine zone that reported by analysis of groundwater samples collected from Wadi Bih well [3]. These are draped over shaded relief maps. Topographic profile shows the change in elevation and aquifer geometry, and therefore, groundwater salinity under the influence of geological lineaments displacements and trends. Rose diagram highlight trends of geological linemanets crosscutting the entire Wadi Al Bih, UAE.

draping locations of groundwater well over maps of extracted geological fractures. Result of spatial analysis shows the positive spatial association and groundwater yield within $50 \mathrm{~m}$ of each other. Further verification of the extracted linear features was made by comparing them against those in the reference maps $[14,24,29]$. The extracted geological fractures using the proposed method are matched and shared similar trends of those in the reference maps, despite the differences in lengths (Fig. 1b).

\subsection{Influence of Geological Fractures on Groundwater Salinity and Groundwater Discharge}

This study, first attempt, investigates the spatial correlation between geological lineaments and hydrological setting and groundwater salinity of Musandam Peninsula including Wadi Al Bih, UAE. The saline zone at the western side of the Wadi Al Bih basin (Fig. 4b) is attributed to the fact that it is very close to three scenarios: the first scenario is that the Wadi Al Bih well field may has experienced sideward and upward Arabian Gulf water intrusion through NNE-SSW and NW-SE trending fault zones, when the groundwater tables deplete under sea level of $85 \mathrm{~m}$. This was confirmed by the presence of the high concentration of chloride anion $\left(\mathrm{Cl}^{-}\right)$and sodium cation $\left(\mathrm{Na}^{+}\right)$at the western side of Wadi Al Bih well and by Confiantini (1992) [12] and [3] who hypothesized that a portion of the Wadi Al Bih aquifer's potentiometric surface is now below Arabian Gulf water level and it was speculated that sea water near the Arabian Gulf has intruded into the aquifer.

The large spatial and temporal in hydraulic conductivity electrical conductivity and $\mathrm{Na}, \mathrm{Cl}^{-}, \mathrm{Ca}^{+}$and $\mathrm{HCO}_{3}$ solutes versus depth and elevation in groundwater samples collected from Wadi Al Bih well field may be due to the area has been affected by WNW-ESE and NE-SW trending fault zone intersections, displacements and faulted blocks (aquifers ge- ometry) subsidence (Fig. 5). The reported saline zone in the western side of Wad Al Bih [3] may be a resultant from Arabian Gulf water intrusion, rain, dissolution of carbonate rocks by chemical weathering and regional brine intrusion $[11,21]$. These results can be suitable parameters to study the role of geological fractures in groundwater salinity by salt accumulation and seawater intrusion. The carbonate rock dissolution by sideward and downward groundwater movements in highly fractured carbonate rocks (limestone and dolomite) appear to be the main reason and source of the high concentration of $\mathrm{HCO}_{3}, \mathrm{Ca}$ and $\mathrm{Na}^{+}$solutes in the Wadi Al Bih wells (Fig. 5). As the distance between source and mouth of Wadis, the probability of high concentration of $\mathrm{HCO}_{3}, \mathrm{Ca}$ and $\mathrm{Na}$ in groundwater increases.

The second scenario is that the carbonate dissolution by lateral groundwater movement from upstreams at an elevation of more than $1900 \mathrm{~m}$ to downstreams at an elevation of $70 \mathrm{~m}(54 \mathrm{~km})$ and by downward groundwater movement may have increased the concentration of $\mathrm{HCO} 3, \mathrm{Ca}$ and $\mathrm{Mg}$ solutes in Wadi Al Bih wells (Figs. 4,5). However, the low salinity, the low electrical conductivity and the high hydraulic conductivity in the eastern part (high elevation) of Wadi $\mathrm{Al}$ Bih well field are attributed to the fact that it is close to the groundwater recharge that is at the foot of Wadi Bih dams.

The extracted linear features were also found to be control the change in elevation and slope gradient from northeast to southwest and from east to west directions. These changes partially control the large variability of groundwater salinity, hydraulic conductivity, aquifer geometry and electrical conductivity (Fig. 5).

Groundwater salinity map (Fig. 5a) suggests that the relatively high in groundwater salinity, electrical conductivity in the western and southwestern parts of Wadi Al Bih well field is from seawater intrusion and carbonate rocks dissolution 

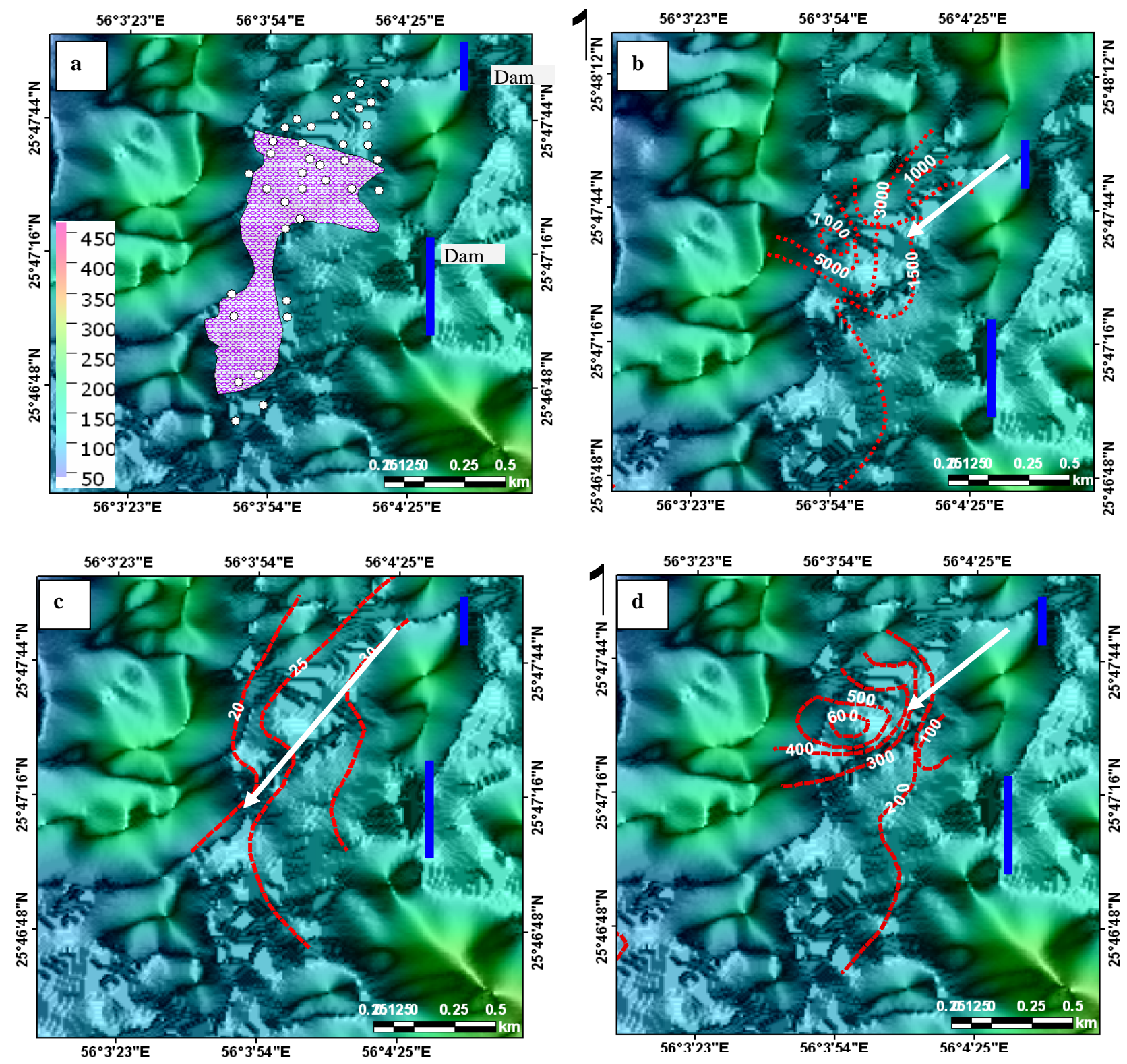

Fig. (5a). Saline zone map, (b) electrical conductivity map, (c) Hydraulic head map, and (d) Iso-concentration (mg/L) contour map of sodium ion in groundwater in Wadi Al Bih. These are draped over shaded relief map (modified after Al Wahedi 1997). White points highlight locations of Bih well field.

along regional geological lineaments that trend N-S, NW-SE and WNW-ESE ((Fig. 4a). This however, due to groundwater table depletion and the aquifer's poteniometric surface below mean sea level (m.s.l) from northeast to southwest (Fig. 5). Finally, it is concluded that the tectonic setting and geological lineaments was found to be control the hydrological setting of the coastal and carbonate aquifers in terms of thickness variation of the alluvial aquifers along Wadis, groundwater deep aquifers storage, groundwater temperature increase, carbonate rock dissolution and groundwater contamination.

\section{CONCLUSIONS}

Unlike traditional methods, topographic fabric algorithm which uses DEM to create map of geological lineaments has proven to be powerful tool to carry out linear features in time and economic effective over multiscales. These features has affected groundwater recharge, ground discharge and groundwater salinity in the carbonate aquifer. Their orientations were found to be in the NE-SW,NW-SE,NNESSW,NWW-SEE and WNW-SES directions. Spatial analysis of geological lineaments trends and samples of groundwater collected from Al Bih well field suggest aquifer geometry, and therefore, groundwater quality and groundwater quantity are structural controlled.

The groundwater salinity in Wadi Al Bih well field is dominated by $\mathrm{Ca}^{+}, \mathrm{Cl}^{-}, \mathrm{Na}^{+}$and $\mathrm{HCO}_{3}$ solutes, indicating dissolution of highly fractured carbonate rocks, Arabian Gulf water intrusion, stream termination and salt accumulation in small depressions, as revealed by remote sensing data. The relative variability of hydraulic head, groundwater salinity and electrical conductivity in Wadi Al Bih from east to west and from north to south are characteristics of highly fractured groundwater aquifers. The proposed methods represent a powerful and effective alternative to field observation and 
photo interpretation methods. The proposed method suggests that by integrating remote sensing data and samples collected from groundwater wells, the locations of groundwater potential and sources of groundwater salinity can determined.

\section{CONFLICT OF INTEREST}

The authors confirm that this article content has no conflicts of interest.

\section{ACKNOWLEDGEMENT}

Declared none.

\section{REFERENCES}

[1] Abu Al Enien H. Wadi Al Bih alluvial fan water resources. Statistical Report Publ. no. 198, Kuwait: Al Kuwait University, Geography Department, 1996; p. 78.

[2] Al Assam MS. Application of geophysical and geochemical techniques for assessment of groundwater recharge from Wadi Al Bih Dams, Ras Al Khaimah, United Arab Emirates. M.Sc. Thesis. United Arab Emirates: UAE University, Al Ain, 1998

[3] Al Wahedi AA. Assessment of environmental impact of reinjecting oil-field water in the miocene clastic sediments on the shallow aquifer at Bu Hasa oil field, United Arab Emirates. M.Sc. Thesis. United Arab Emirates: UAE University, Al Ain, 1997.

[4] JICA. (Japan International Cooperation Agency). The master plan study on the ground water resources development for agriculture in the vicinity of Al-Dhied in the UAE. Final Report. UAE: Ministry of Agriculture and Fisheriar (MAR). 1996.

[5] Lattman LH, Parizek RR. Relationship between fracture traces and the occurrence of groundwater in carbonate rocks. J Hydrol 1964; 2: 73-91.

[6] Mabee SB, Hardcastle KC, Wise DW. A method of collecting and analyzing lineaments for regional-scale fractured bedrock aquifer studies. Ground Water 1994; 32: 884-94

[7] Ollier CD. Tectonics and landforms.Geomorphology texts, 6. New York: Ongman Group Limited. 1981; p. 324.

[8] Shaban A, Khawlie M. Geoenvironmental assessment through remote sensing of fresh water sources between Beirut and Anfeh coastal stretch (1972-1997). Proc 4th Int Conf Geology of the Middle East; 1998 Nov 9-12; ESCWA, Beirut 1998; pp. 181-9.

[9] Fetter CW. Applied hydrology. $3^{\text {rd }}$ ed. New York: Macmillan 1994; p. 691.

[10] Murad AA, Al Nuaimi H, Al Hammadi M. Comprehensive Assessment of Water Resources in the United Arab Emirates (UAE) Water Resour Manag 2006; 21(9): 1449-63.

[11] Sener A, Davraz A, Ozcelik M. An integration of GIS and remote sensing in groundwater investigations: a case study in Burdur, Turkey. Hydrogeol J 2005; J13: 826-34.
[12] Gonfiantini R. On the isotope composition of precipitation. In: Fontes JC (1936-1994) Un souvenir, Proceedings International Symposium. Eur Geol 1995; 2:5-8.

[13] Panizza M, Castaldini D, Bollettinari G, Carton A, Mantovani F. Neotectonic research in applied geomorphological studies. Zeitschrift für Geomorphol 1987; 63: 173-211.

[14] Samy I. Remote sensing For hydrological application. In The vicinity of AL-Dhied Area, UAE. Maser Thesis. Malaysia: University Technology Malaysia, Faculty of Geoinformatics, Remote Sensing Department 2006.

[15] Florinsky IV. Quantitative topographic method of fault morphology recognition. Geomorphology 1996; 16(2): 103-19.

[16] Ganas A, Pavlides S, Karastathis V. DEM-based morphometry of range-front escarpments in Attica, central Greece, and its relation to fault slip rates. Geomorphology 2005; 65(3-4): 301-19.

[17] Oguchi T, Aoki T, Matsuta N. Identification of an active fault in the Japanese Alps from DEM-based hill shading. Comput Geosci 2003; 29(7): 885-91.

[18] Sander P, Minor TB, Chesley MM. Groundwater exploration based on lineament analysis and reproducibility tests. Ground Water 1997; 35(5): 888-94.

[19] Sander, P, Chesley, MM, Minor TB. Groundwater assessment using remote sensing and GIS in a rural groundwater project in Ghana: lessons learned. Hydrogeol J 1996; 4: 40-9.

[20] Hunting Geology and Geophysics Ltd. Geological map of the United Arab Emirates, United Arab Emirates: Ministry of Petroleum and Mineral Resources. Al Ain, 1979a.

[21] Hunting. Mineral survey of the U.A.E. 1977-1979. Abu Dhabi, UAE: Ministry of Petroleum and Mineral Resources 1979; pp. 1-34

[22] United Arab Emirates (UAE). Climatological data, vol 3. Abu Dubai UAE: Ministry of Agriculture and Fisheries, Department of Soil and Water 1993; p. 443

[23] United Arab Emirates (UAE). Hydrology. vol 3. Abu Dhabi, UAE: Ministry of Agriculture and Fisheries, Department of Soil and Water 1993; pp. 294.

[24] Glennie KW, Boeuf MG, Hughes M, et al. Geology of the Oman Mountains, Parts 1 and 2. Utrecht, The Netherlands: The Royal Dutch Geological and Mining Society (KNGMG) 1974; p. 423.

[25] Available at: http://www.gdem.aster.ersdac.or.jp/search.jsp

[26] Hengl T, David G. Rossiter. supervised landform classification to enhance and replace photo-interpretation in semi-detailed soil survey soil. Sci Soc Am J 2003; 67: 1810-22.

[27] Available at: https://zulu.ssc.nasa.gov/mrsid

[28] Guth PL. Eigenvector analysis of digital elevation models in a gis: geomorphometry and quality control. In: Evans IS, Dikau R, Tokunaga $\mathrm{E}$, Ohmori $\mathrm{M}$, Hirano $\mathrm{H}$, Eds. Concepts and modelling in geomorphology: international perspectives. Tokyo: TERRAPUB 2003; pp. 199-220

[29] UAE University. United Arab Emirates (UAE), National Atlas. UK: GEOprojects 1993.

\begin{tabular}{lll}
\hline Received: August 10, 2011 & Revised: November 30, 2011 & Accepted: January 2, 2012
\end{tabular}

() Elmahdy and Mohamed; Licensee Bentham Open.

This is an open access article licensed under the terms of the Creative Commons Attribution Non-Commercial License (http://creativecommons.org/licenses/by-nc/3.0/) which permits unrestricted, non-commercial use, distribution and reproduction in any medium, provided the work is properly cited. 